\title{
Aboriginal and Torres Strait Islander peoples and multinational federalism in Australia
}

\author{
Harry Hobbs
}

\begin{abstract}
Democratic governance is premised on the belief that all citizens are empowered to shape the society in which they live. Over generations, Aboriginal and Torres Strait Islander peoples have maintained that Australian democratic practice does not live up to this ideal, contending that the state's legal and political framework does not empower them with the capacity to have their voices heard and their interests considered in the processes of government. However, non-Indigenous Australians remain suspicious of Indigenous-specific political and legal mechanisms designed to rectify this structural fault. In this paper, I argue that this suspicion - and Australia's governance framework more broadly - arises from a particular conception of democratic theory that marginalises Aboriginal and Torres Strait Islander peoplehood. If, as the Uluru Statement from the Heart calls for, Australia's political institutions are to be rebuilt so as to empower Aboriginal and Torres Strait Islanders 'to take a rightful place in [their] own country', that conception of democratic theory must first be revealed and re-centred. Multinational federalism offers one path towards a more equitable future.
\end{abstract}

\section{Introduction}

In May 2017, around 250 Aboriginal and Torres Strait Islander delegates from 'all points of the southern sky' gathered on the red dust of Mutitjulu to call for meaningful reform to Australia's democratic institutions. ${ }^{1}$ The largest and most comprehensive process of deliberative constitutional debate in the country's history, the Uluru Statement from the Heart echoes and extends generations of Indigenous advocacy. For over a century, Aboriginal and Torres Strait Islander peoples have challenged Australia's political and legal governance framework, contending that it fails to substantively recognise their normative distinctiveness and fails to accommodate their aspirations. As part of this political activism, Aboriginal and Torres Strait Islander peoples have frequently asserted that 'democracy has failed' them, ${ }^{2}$ or that democracy 'just does not work to enable the solution of our problems'. ${ }^{3}$ Is democracy the problem?

In this article, I argue that democracy is not the problem; Australian democratic practice is. Democratic theorists recognise the necessity of counter-majoritarian mechanisms to restrain untrammelled majorities as well as to empower minority groups who are unable to protect themselves in majoritarian processes. ${ }^{4}$ The problem is that in Australia, these countermajoritarian mechanisms are not structured along cleavages relevant for Aboriginal and Torres Strait Islander peoples. This is because Australia's political and legal governance framework is built on a unitary conception of the demos that obscures the challenges faced by numerically small, distinct, normative communities seeking to have their interests considered in the 
processes of government. I argue that recognition that Australia is a plurinational state, consisting of multiple peoples, is key to devising and constructing appropriate legal and political institutions and processes to empower Aboriginal and Torres Strait Islander peoples in a manner consistent with democratic values.

The argument is carried out in two parts. Part II explains that Australian democratic practice is largely premised on the idea of a 'culturally homogenous nation'. ${ }^{5}$ Within the Australian community, the formal political resources are, in theory at least, distributed equally; all persons are members of a 'single-status community', ${ }^{6}$ enjoying undifferentiated citizenship rights. Formal political equality secures important democratic outcomes, but it can also promote a false dichotomy between equality and difference that, in Australia, operates to deny the peoplehood status of Aboriginal and Torres Strait Islanders. ${ }^{7}$ As I argue, this intellectual construction', ${ }^{8}$ has informed the design of a governance framework that fails to empower Aboriginal and Torres Strait Islander peoples.

In Part III, I reconstruct Australian democratic practice by re-centring it on Aboriginal and Torres Strait Islander peoplehood. Grounding our political and legal governance framework on the fact that multiple normative orders exist within the state leads us to consider institutional arrangements that more equitably distribute political power in a manner consistent with democratic ideals. Many democratic states across the globe are increasingly acknowledging that the Indigenous polities whose land they claim are entitled to a measure of political power and are consequently developing or recognising institutions of self-rule for Indigenous political communities within an overarching framework of shared-rule. Difficult questions concerning the boundaries of Indigenous polities, as well as the delineation of legal authority and political responsibility persist, but democratic theory points towards a more equitable, albeit contested, solution.

Before commencing this project, however, two preliminary points are necessary. First, exploring Aboriginal and Torres Strait Islander peoples' constitutional or political relationship with the Australian state under the lens of democratic theory is justifiable only if Indigenous Australians do not desire to secede. This appears to be the case. Despite several prominent figures advocating for stronger forms of autonomy, ${ }^{9}$ many Aboriginal and Torres Strait Islander people appear to seek reform of, rather than outside, the state. As the Uluru Statement from the Heart confirmed, many Indigenous Australians desire 'substantive constitutional change and structural reform' so that their 'ancient sovereignty can shine through as a fuller expression of Australia's nationhood' and that they make take 'a rightful place in [their] own country' ${ }^{10}$ As explained at Uluru, sovereignty is not a legal concept but 'a spiritual notion', ${ }^{11}$ predicated on Indigenous Australians' ancestral ties to land and community. Assertions of Indigenous sovereignty therefore do not necessarily call for legal secession but for meaningful institutional change to embed a constitutional relationship built on equal partnership and equal political status.

Second, democratic theory is an especially useful framework of analysis because the reforms expressed in the Uluru Statement are multifaceted and intimately connected to democratic ideals. In calling for a First Nations Voice to advise the federal Parliament, Aboriginal and Torres Strait Islander peoples reveal their aspirations for institutional reform that empowers them to be heard in processes of shared decision-making. In also calling for a Makarrata Commission to supervise a process of agreement-making and truthtelling, Indigenous Australians documented their desire that the state carve out legal space for distinct Indigenous communities to make their own decisions. These reforms are aimed at developing quasi-federal 
institutional arrangements. In this sense, they are 'the fulfilment of a greater democracy', ${ }^{12}$ aimed at empowering Indigenous peoples with the capacity to have a say in government in a manner that allows them to impose a direction on that government, ${ }^{13}$ so they may "shape the social context in which they live'. ${ }^{14}$

\section{Australian democratic practice}

Aboriginal and Torres Strait Islander peoples were historically excluded from the Australian polity. Indigenous peoples played no meaningful role in the drafting of the Constitution, ${ }^{15}$ which expressly discriminated against them $;{ }^{16}$ formal prohibitions on the franchise were in place until 1962, ${ }^{17}$ and it was not until 1967 that symbolic and practical constitutional exclusions were excised. These important reforms opened the Australian demos to Aboriginal and Torres Strait Islander peoples and contributed to a more inclusive understanding of Australian identity. However, they have proven insufficient to empower Indigenous Australians because they were not accompanied by formal recognition of Indigenous normative distinctiveness nor institutional arrangements to give such distinctiveness political or constitutional force. ${ }^{18}$ Consequently, prevailing social and political attitudes that initially excluded Aboriginal and Torres Strait Islander peoples are today reflected in a legal governance framework that fails to empower Indigenous Australians with the capacity to have their voices heard and their interests considered in the processes of Australian government.

\section{A. The unitary demos}

Marginalisation and denial of Indigenous normative distinctiveness is interlinked with Australian conceptions of democracy. As Megan Davis has argued rejection of Indigenous difference arises from the "utilitarian ethic'19 that dwells within Australia's sense of egalitarianism and that marks anything 'special' as necessarily 'violating the sameness that is at the core of the national identity'. ${ }^{20}$ These logics also lay behind Prime Minister John Howard's persistent refusal to contemplate negotiating a treaty with Aboriginal and Torres Strait Islander peoples, for as he explained, 'a united undivided nation does not make a treaty with itself' ${ }^{21}$ Implicit in Howard's rejection of treaty-making is a particular understanding of democracy that operates as the premise for Australia's political and legal governance framework. For Howard, Australia is composed of a single people. ${ }^{22}$ That is, despite the multiplicity of citizens within the polity, as an 'imagined community', ${ }^{23}$ a 'presumed homogeneity' ${ }^{24}$ permeates Australian society. Because all members of the polity are members of a single community, 'no group... should have rights that are not enjoyed by another group' ${ }^{25}$

Assertions of Indigenous difference challenge the unitary demos and its difference-blind treatment of equality. Aboriginal and Torres Strait Islander peoples argue that their status as prior, self-governing normative communities who have never ceded sovereignty distinguish themselves from other citizens of the state. ${ }^{26}$ They contend that they are not simply ethnic or cultural minority groups, but polities with concomitant rights entitled to a distinctive institutional relationship with the state. This status is reflected in international soft law instruments; the United Nations Declaration on the Rights of Indigenous Peoples (UNDRIP), for instance, endorsed by Australia in 2009, affirms Indigenous peoples distinctive character, adopting a multinational ordering of the state. ${ }^{27}$ This status is also reflected in some domains in Australia. As Dylan Lino has explained, the Australian state has legally recognised the peoplehood of Aboriginal and Torres Strait Islanders in three major forms: the establishment of distinct entitlements to land; ${ }^{28}$ protection of cultural heritage; ${ }^{29}$ and the emergence of an Indigenous sector to 'represent, deliver services to and manage land for Aboriginal and Torres 
Strait Islander peoples' ${ }^{30}$ However, while these legislative and political advances suggest that Australian democracy is capable of recognising group claims in many practical ways, these successes are only partial; this distinctive status is not recognised more fundamentally in Australia's political and legal institutions.

Australia's democratic institutions do not specifically empower Indigenous peoples to be heard. Rather, reflecting a conception of formal equality consistent with the existence of a singular people, Aboriginal and Torres Strait Islander peoples enjoy the same opportunities and responsibilities as all Australian citizens. Among other democratic rights, Indigenous Australians may stand for Parliament, freely discuss political and governmental matters, and assemble and associate for that purpose. Although Indigenous peoples constitute a numerical minority within the Australian state, a complex public law framework is intended to appropriately balance the value of democratic rule against the danger of de Tocqueville's 'tyranny of the majority'. Political power is divided horizontally across a bicameral parliament and vertically via division of competencies between the federal government and eight states and self-governing territories, while the judiciary is empowered to check legislative and executive action in certain areas. Together, this institutional framework is expected to provide all citizens with 'an equal share in political power'. ${ }^{31}$

Aboriginal and Torres Strait Islander people consistently maintain, however, that this framework, and Australian democratic practice, does not provide them with an 'equal share in the political life of the community'. ${ }^{32}$ Australia's system of governance is 'built upon confidence in a system of parliamentary' representation, ${ }^{33}$ but demographics, electoral system design, and political practice challenge Indigenous Australians' capacity to elect representatives of their choice. When combined with the absence of comprehensive rights protections or a requirement that government 'listen to Indigenous peoples before passing laws that affect [them]', ${ }^{34}$ the result is a government largely 'not accountable to Indigenous peoples'. ${ }^{35}$ Overall, Australian democratic institutions generally do not protect Indigenous peoples from majority rule, nor empower them to shape the social context in which they live.

Institutional reform is necessary to rectify this breach of democratic values. However, the underlying conception of democracy that operates in Australia leads non-Indigenous Australians to view Indigenous-specific political and legal processes and institutions aimed at remedying Indigenous marginalisation with suspicion. For example, the question of reserved seats in parliament for Indigenous Australians has periodically been examined by parliamentary and expert bodies. Although the New Zealand Parliament has included dedicated seats for Māori people since $1867,{ }^{36}$ (and added provisions to increase their number in 1993), ${ }^{37}$ no Australian report has recommended its adoption. Rather, concerns are frequently noted that the community considers the idea of reserved seats 'undemocratic' ${ }^{38}$ More recently, Prime Minister Malcolm Turnbull echoed these concerns in rejecting the proposals of the Uluru Statement from the Heart. In a press release, Turnbull explained that 'our democracy is built on the foundation of all Australian citizens having equal civic rights', and that a constitutionally enshrined Indigenous representative body empowered to advise the Parliament would "undermine the universal principles of unity, equality and "one person one vote". 39

This underlying conception of democracy manifests in various guises. In 2007, it animated the reasons given by representatives of Australia, Canada, Aotearoa/New Zealand and the United States for refusing to adopt the UNDRIP. Representatives from Australia and Canada remarked that they could not accept an instrument that would 'apply a standard for Indigenous peoples that does not apply to others in the population', for allowing 'a particular subgroup of the 
population to be able to veto legitimate decisions of a democratic and representative government ${ }^{40}$ is 'fundamentally incompatible with [our] parliamentary system' ${ }^{41}$ Similarly, the Aotearoa/New Zealand representative explained they were unable to support articles in the Declaration that implied 'different classes of citizenship' or that 'Indigenous peoples have rights that others do not have'. ${ }^{42}$ In a separate statement, Robert Hagan, the United States representative, declared that while the United States 'strongly support the full participation of Indigenous peoples in democratic decision-making processes' it 'cannot accept the notion of a sub-national group having a "veto" power over the legislative process' ${ }^{43}$ Each nation has since adopted the Declaration, and while their initial demurrer may have been more complicated, ${ }^{44}$ their statements remain telling.

Similar concerns catalysed opposition to the Aboriginal and Torres Strait Islander Commission (ATSIC). Operating between 1990 and 2005, ATSIC delivered limited, but real authority to Aboriginal and Torres Strait Islander people. As a nationally representative body with executive powers, Indigenous representatives could identify funding priorities, formulate and implement regional plans, make decisions over public expenditure, protect cultural material and information, and speak directly to the government. ${ }^{45}$ As such, its existence served as an acknowledgment that public policy affecting Indigenous Australians should not be devised and implemented by the Australian population as a whole but by those affected by it. Consequently, the Commission directly challenged the dominant narrative of Australian democracy, inviting virulent criticism. During debate on the ATSIC Bill in 1989, for instance, Opposition Leader John Howard condemned the Commission as 'a monumental disservice to the Australian community' which 'strikes at the heart of the unity of the Australian people'. ${ }^{46}$ Other members of the Opposition adopted similar attacks, criticising the proposed body as a 'black parliament', ${ }^{47}$ which 'smacks of separatism of the worst possible kind in a nation'. ${ }^{48}$

This language periodically reappeared in debate over ATSIC throughout its life and ultimately served as a justification for its eventual abolition in $2005 .{ }^{49} \mathrm{In}$ announcing this decision, Prime Minister Howard declared that the 'the experiment in separate representation, elected representation, for Indigenous people has been a failure' ${ }^{50}$ Standing beside him, Amanda Vanstone, the Minister for Immigration and Multicultural and Indigenous Affairs defended the decision, noting that 'there was once a country we wouldn't play cricket with because they had separate systems' ${ }^{51}$ Later that year, Vanstone again gave voice to the prevailing conception of Australian democracy, remarking in an address to the Bennelong Society that 'for too long we have let ideological positions like self-determination prevent governments from engaging with their Indigenous citizens' ${ }^{52}$ For Vanstone, the Commission - and the very notion of Indigenous difference - demarcated Aboriginal and Torres Strait Islander peoples from other Australians in a manner incompatible with democracy.

Australian democracy is built (and maintained) on an account that assumes the polity constitutes a single national community. ${ }^{53}$ This conception contends that the view that Indigenous Australians might be differentiated from other members of the state, and consequently, might have different rights and obligations is 'fundamentally incompatible' with democracy. It is this understanding that catalysed opposition to ATSIC, lay behind Australia's refusal to endorse the UNDRIP in 2007, and continues to challenge putative Indigenousspecific mechanisms today. As I argue below, this understanding has led to a governance framework that fails to empower Aboriginal and Torres Strait Islander peoples, contributing to the 'torment of [their] powerlessness'. ${ }^{4}$ 


\section{B. The misguided institutional framework}

The boundaries of the possible are set in advance by the parameters of our imagination. It is no surprise then that the subconscious supposition of a "monistic demos ${ }^{55}$ grounds certain philosophical presumptions within Australian democratic practice and, consequently, the political and legal institutions and processes that structure the operation of Australian governance. Indigenous peoplehood may have been recognised in several ways and the Australian citizenry may be less homogenous than it historically has been, but, as Aileen Moreton-Robinson has noted, 'the dominant institutions such as law and government, and their epistemologies, remain anglicised'. ${ }^{56}$ In this section, I explore three consequences for Aboriginal and Torres Strait Islander peoples that follow from the prevailing conception of democracy that operates in Australia.

First, the assumption that within Australia resides one unified national community affects the formulation of citizenship rights and duties, which apply equally to all citizens irrespective of their identity. While securing the valuable democratic goal of equal citizenship, the application of this formally neutral vision of justice and fairness can 'serve to overlook deeply imbalanced relations of power' between peoples within the state. ${ }^{57}$ Indeed, incorporating distinct peoples into a larger undifferentiated mass of formally equal citizens does not negate the reality of contestation (and potentially domination) between different polities, but it does ensure that state institutions and mechanisms are blind to this fact. As such, institutional forms to guard against the formation of, or specifically empower, a persistent electoral minority may be absent. ${ }^{58}$

The extension of the franchise to Aboriginal and Torres Strait Islander peoples serves as an appropriate example. Clearly, removing discriminatory legislation and ensuring that 'everyone who is affected by the decisions of a government [has the] right to participate in that government', ${ }^{59}$ secured democratic goals. But, in the absence of legal or political institutions or processes to recognise the distinctive status of Aboriginal and Torres Strait Islander peoples, at what cost were democratic goals secured? The extension of the franchise and its compulsory application 'usurped' Indigenous polities, swallowing them up into a larger state that negates the reality of their status as prior self-governing communities ${ }^{60}$ erasing the existence of "shared membership in separate or overlapping polities' ${ }^{61}$ In a process that Ephraim Nimni terms 'assimilation with democracy as compensation', ${ }^{62}$ the extension of the franchise welcomed Indigenous peoples into a form of governance based upon majority rule and predicated on participation as atomistic individuals. Comprising only 3 per cent of the total population and territorially dispersed across the political unit, the formal non-recognition of normative difference ensures that - notwithstanding their equal right to speak, protest, and vote Indigenous Australians will struggle to be heard via democratic mechanisms. ${ }^{63}$

The failure to question the unitary demos assumption frames past 'exclusion' from the body politic as the sole problem of justice facing previously excluded groups. Thus, inclusion is perceived as the necessary remedy. ${ }^{64}$ This may be appropriate for many groups, including women and the propertyless, but it is in tension where civil rights or civic inclusion projects interact with groups who consider themselves a distinct people. As the significantly lagging registration and participation levels of Aboriginal and Torres Strait Islander peoples in Australian elections indicates, ${ }^{65}$ for such groups, inclusion in the civic project is necessary but not sufficient, for the civil rights project cannot address issues of competing sovereignties. ${ }^{66}$ Simply put, for many Indigenous peoples, equal rights within an undifferentiated community constitutes a denial of their distinctive status. 
Second, a belief that the Australian polity constitutes a shared national community leads to a view that the potentially destructive effects of majoritarian mechanisms are somewhat mitigated, or unlikely to eventuate. Where the citizens of a state share a deep sense of belonging, solidarity can be expected notwithstanding that some group of voters is in a minority and their policy preferences are not enacted. This assumption is inherent in John Rawls' privileging of a shared conception of justice as the foundation for unity in modern societies. For Rawls, although a 'well-ordered society is divided and pluralistic' and therefore cannot achieve agreement in all things, 'the public agreement on questions of political and social justice supports ties of civic friendship and secures the bonds of association' ${ }^{67}$ Indeed, despite their electoral loss, in the United Kingdom members of Her Majesty's Loyal Opposition remain 'firmly part of the demos' ${ }^{68}$ anxious to ensure their alienation from the government benches is only temporary.

This same assumption leads many theorists to contend that persistent electoral minority groups do not exist. Majority rule is entirely unproblematic because 'constantly shifting constellations of various minority interests ${ }^{69}$ will coalesce around certain issues before breaking apart and rearranging themselves on other points, and we therefore all take turns ruling and being ruled. As only a "fanatic or a compulsive neurotic ${ }^{70}$ places stock in a single group affiliation, countermajoritarian institutions need not cleave so closely to such distinctions. In plurinational states like Australia, however, this basic sense of shared identity cannot be presumed and, therefore, may not compensate recurrent or persistent electoral defeats on issues that strike at the heart of a people who consider themselves, in some part, separate from the dominant community. ${ }^{71}$ While persistent electoral defeats do not inexorably lead to civil strife or insurrection they can further weaken bonds of solidarity, dissolving social and institutional trust. For many Aboriginal and Torres Strait Islander people, the very legitimacy of the presently constituted Australian state is at issue. In these circumstances, public agreement on political justice cannot be taken for granted and solidarity cannot be expected. Institutional design must be sensitive to this fact.

Finally, a failure to appreciate relevant distinctions means Australia's democratic institutions mischaracterise diversity as always cultural rather than sometimes national. Consequently, our counter-majoritarian mechanisms are not designed for plurinational politics, but pluricultural or pluralist ones. That is, they appreciate pluralism within a single Australian community, but not the pluralism of multiple peoples within the state. For instance, while only the Australian Capital Territory and Victoria have enacted statutory bills of rights, ${ }^{72}$ efforts are mobilising to pass similar bills in other jurisdictions. ${ }^{73}$ These are positive developments, but it is important to be clear-eyed about their potential. Although the logics of human rights instruments may support some Indigenous aspirations, ${ }^{74}$ they only stretch so far. ${ }^{75}$ In framing the legal limits of government action, human rights instruments regulate state power rather than challenge it, and they are not suitable mechanism to recognise the distinctive status of a people. ${ }^{76}$

Federalism may sometimes operate as a counter-narrative to the construction of a unitary demos during constitutive periods, but this was not the case here. In Australia, the division of competencies was premised on an understanding of federalism that sees political subunits as primarily historically derived administrative arrangements, rather than a flexible means to accommodate the democratic rights of multiple peoples. Australia's states and territories are predominantly creatures of managerial ease, arising from the difficulty in exercising control and governance over a continent in the nineteenth century. While each colony contained significant ethnocultural pluralism, ${ }^{77}$ each 'demos' was regarded as - and via coercive 
measures, designed to be - one and the same. This central fact was recognised by the future Australian Prime Minister Alfred Deakin, in his response to the then South Australian Premier Charles Kingston at the Federal Convention Debates at Melbourne in 1890:

The honourable gentleman seemed to imply that there would always be the same separateness existing between the residents of the Australian Colonies as there may be between the residents of adjoining but differing nationalities. We have, however, to recollect that we have sprung from one stock and are one people, and whatever the barriers between us may be, they are of our own creation. That which we have created we are surely strong enough to remove. ${ }^{78}$

Deakin's understanding of Australian unity was shared by many - if not all - of the delegates. Famously, at a Federation Conference Banquet in 1890, Henry Parkes, the 'Father of Federation', characterised the relationship of the peoples of the colonies as bound together by a 'crimson thread of kinship'. ${ }^{79}$

Invocations of blood may no longer feature in mainstream accounts of Australian identity but the failure to recognise diverse peoples within the state has left Australian federalism somewhat inchoate. Indeed, as William Riker remarked, 'one wonders indeed why they bother with federalism in Australia'. ${ }^{80}$ In recent years, however, scholarly work has proposed ways to reconceptualise our 'territorial' understanding of federalism into a 'multinational' approach. ${ }^{81}$ For example, Michael Mansell has advocated the establishment of an Aboriginal State within the Australian federation, comprising of existing Indigenous landholdings, ${ }^{82}$ while Dylan Lino has explored how this institutional mechanism may offer a 'valuable conceptual language' for framing Indigenous peoplehood claims. ${ }^{83}$ Notwithstanding these impressive and innovative efforts, there appears little political appetite to progress alternative conceptions. Federalism in Australia remains wedded to A. V. Dicey's contention that 'an impress of common nationality' is necessary. ${ }^{84}$ This is problematic. A multinational account of federalism offers many advantages, including the potential to anchor Indigenous and non-Indigenous polities within an overarching shared framework based on a robust democratic constitutional system that divides powers equitably between distinct polities. Such an approach could thus provide the building blocks for mechanisms designed to empower Aboriginal and Torres Strait Islander peoples in a manner consistent with democratic ideals. ${ }^{85}$ Multinational federalism in Australia is only possible, however, if we jettison prevailing understanding of Australian democracy and recognise Indigenous political communities as 'an equal partner in the state' ${ }^{86}$

\section{III.Re-centring Australian democratic practice}

Australia's democratic institutions are built on exclusion. The Australian Constitution imposed a foreign system of law and government, displacing diverse normative orders across the continent with a single legal framework that cast Indigenous peoples out of the "constitutional community' ${ }^{87}$ Law reform may have since welcomed Indigenous peoples into the Australian polity, but their inclusion was not accompanied by meaningful amendment to the framework of governance. Democratic institutions developed for a polity predicated on their absence continue to regulate Aboriginal and Torres Strait Islander peoples' relationship to and with government.

In this part, I begin the project of rehabilitating Australian democratic practice by displacing its presumption of a unitary demos and exploring institutional forms that recognise Australia's plurinational foundations. Grounding Australia's political and legal governance framework on the fact that multiple normative orders exist within the state suggests forms of institutional 
design that distribute political power across and within Indigenous and non-Indigenous polities who share this continent. Drawing on Aboriginal and Torres Strait Islander aspirations as reflected in the Uluru Statement from the Heart and comparative institutional mechanisms from across the globe, this part justifies and explores mechanisms of self-rule and shared-rule within democratic frameworks. It argues that re-centring Australian democratic practice along these lines will empower Aboriginal and Torres Strait Islander peoples in a manner consistent with democratic ideals.

\section{A. Reconstituting the demos: Uncovering multiple political communities}

The notion that the Australian state is (or should be) composed of a unified, undifferentiated, national community is a powerful one. It accords with the animating ideal of democracy as well as the concept that grounds the political (if not legal) legitimacy of the Australian government: popular sovereignty. ${ }^{88}$ Popular sovereignty does not presuppose democratic government - a tyrant may claim to represent the will of the people and rule in their name but democracy itself is intimately connected to this amorphous concept, for it is the collective will of the people, understood as the ultimate source of political power, that legitimates coercively backed decisions. ${ }^{89}$ Implicit in many conceptions of popular sovereignty then, is an understanding of the polity in a unitary sense, as state actions are conceived as the "expression of a singular people' ${ }^{90}$

Uprisings against monarchical rule in the United States and France in the late eighteenth century first illustrated that the modern doctrine of popular sovereignty may lead to the construction of a unitary demos. Without a sovereign demanding loyalty and obedience, the new regimes recognised something else was required to maintain solidarity and cohesion to ensure that the people living within their territorial control could imagine themselves as a community. The idea of the nation solved this problem, ${ }^{91}$ by identifying 'a circumscribed body of people bound together by a common custom and capable of being represented by a prince or parliament'. ${ }^{92}$ The 'instinctive and, in a sense, involuntary accord which springs from like feelings and similar opinions ${ }^{93}$ of members of the same nation, became seen as a 'necessary condition of [democratic] institutions'. ${ }^{94}$

Constructing the nation required realising important democratic goals. Legal stratification, corporatist social arrangements and hierarchical relationships characteristic of the Middle Ages were levelled, establishing, at least in theory, a single-status community. ${ }^{95}$ In France, for example, the Estates-General, whose members had been elected to represent the three estates of the realm: the clergy, the nobility, and the commoners, was abandoned in favour of the revolutionary National Constituent Assembly, composed entirely by an undifferentiated populace. Two months into its existence, the Assembly promulgated the Declaration of the Rights of Man and Citizen, pronouncing that 'the law is the expression of the general will' and 'it must be the same for all' ${ }^{96}$ While positive in opening 'the door to a more broadly participatory form of government, based on principles of governmental accountability and popular consent', ${ }^{97}$ popular sovereignty - and democracy - came to be centred on an 'undivided and all-inclusive community as the basis of a single unified decision-making power' ${ }^{98}$

The concept of the 'the sovereign people' is therefore not only a manifestation of the authority of the citizens of a particular territory, but also a unifying device that can serve to construct a monistic and uniform demos. Indeed, as James Tully has argued, invocations of popular sovereignty can 'eliminate... diversity as a constitutive aspect of politics', ${ }^{99}$ because to have 
any weight 'the people' must be constructed as 'culturally homogenous' in the sense that cultural differences are transcended or irrelevant. ${ }^{100}$ Simone Chambers concurs, noting that 'the people' have no particular identity, but exist as a generalised 'distillation of the common points of interest shared by all men of good will and reason'. ${ }^{101}$ The assumption that 'citizens belong indiscriminately to the demos', Geneviève Nootens has explained, lies 'at the heart' of the modern doctrine of popular sovereignty and contemporary representative democracy. ${ }^{102}$

Democratic government does not always rest on a unitary conception of the polity. As Scotland, Catalonia, and Quebec demonstrate, extant democratic states can accommodate (albeit with some contestation) plural peoples sharing a state. The problem is, however, that democratic theorists have traditionally struggled to identify plurinational states and instead have taken the unitary demos for granted. As Robert Dahl has explained, the challenge for democratic theorists seeking to identify a polity is a conceptual one: before the people can vote to decide who shall be included and where the boundaries of the political community shall be placed, they must reach consensus over who can take part in the voting in the first place. ${ }^{103}$ This central difficulty has meant that democratic theorists have struggled to explore "questions about [democratic theory's] scope', ${ }^{104}$ as political philosophers "characteristically presuppose that "a people" already exists'. ${ }^{105}$ In fact, many theorists have simply suggested that democratic theory lacks the tools to solve this problem, arguing that we should work with historically given solutions, ${ }^{106}$ or instead 'isolate' this difficulty by focusing on states whose territory is already welldefined. ${ }^{107}$ As the previous part demonstrated, however, in Australia this 'solution' has led to institutional forms that fail to empower peoples not connected to the state-demos. Re-centring Australian democratic practice, begins then, by exploring the problem of 'constituting the demos' ${ }^{108}$ In other words, it begins from a simple question: if democracy requires that all members of the polity be included in the decision-making process and have an equal opportunity to influence the outcome, ${ }^{109}$ where can the borders of the polity be drawn, and where can jurisdictional authority be delineated?

Two major approaches to this problem can be discerned from the literature, distinguished by whether they adopt an internal or external lens. First, some scholars, like Kirsty Gover, examine democratic theory's boundary problem by reference to tribal membership of Indigenous political communities. ${ }^{110}$ Gover's analysis speaks to real challenges facing Indigenous nations who seek to maintain control over their community in the face of settler state imposition. Her focus is internal, however, and does not suggest an answer to how settler-state legal and political processes should be restructured to promote the ability of Indigenous people to have a say in settler-government in a manner that allows them to impose a direction on that government.

An external focus that explores the relationship between Indigenous nations and the settlerstate in which they live offers greater potential. Unfortunately, many liberal social contract theorists addressing the problem of constituting the demos in this way do not engage with the position of Indigenous peoples. ${ }^{111}$ Rather, by reference to, for example, regulatory concerns over environmental pollution, they argue for broadening the boundaries of the demos to include all people affected by a decision. ${ }^{112}$ This 'all-affected' principle aims at radically democratising decision-making globally but has little to directly say about the structure of decision-making within plurinational states.

Nevertheless, embers of federalism and sub-state nationalism may be detected and revived within this theoretical account. If a case can be made that Indigenous peoples interests are more 'relevantly affected' by certain decisions, then a more restrained all-affected interests principle 
(perhaps infused with notions of subsidiarity) that matches circles of stakeholders with decision-makers, ${ }^{113}$ suggests specific legal and political processes to ensure those interests are heard in decision-making are required. This approach connects with recent scholarly work exploring federalism as a way to reconcile Indigenous peoplehood with democratic settler states. ${ }^{114}$ And, significantly, as Dylan Lino has noted, has the added advantage of 'draw[ing] upon and creatively adapt[ing] Australia's own constitutional traditions'. ${ }^{115}$

\section{B. Self-rule for Indigenous political communities}

A re-centred democratic practice reflective of Aboriginal and Torres Strait Islander peoples' distinctive position and aspirations is built on the recognition of multiple peoples inhabiting a state. Converting Indigenous nationhood into a claim to a 'more equal citizenship' by enhancing the capacity of Aboriginal and Torres Strait Islander peoples to be heard in the processes of existing institutions of Australian government is necessary, but not sufficient. Such an approach remains captive within the assumption of a monistic demos, and, as David Temin explains, would merely 'reproduce the very logic that binds Indigenous peoples to [the] violence of replacement via different forms of incorporation into the polity'. ${ }^{116}$ Instead, a recentred democratic practice suggests that counter-majoritarian mechanisms that recognise Aboriginal and Torres Strait Islander governance rights over matters that more relevantly affect them should be developed. ${ }^{117}$

Considering the heterogeneity of Aboriginal and Torres Strait Islander communities, it is not possible to be prescriptive about the extent of self-government powers that could be recognised. Differently situated communities will have different aspirations and competencies. Although complex, this reality is not indicative of the impossibility of this approach, for, as Patricia Monture-Angus has noted, 'the solution is not about constructing a single (national) model', ${ }^{118}$ but in permitting Indigenous political communities the freedom to self-constitute and negotiate the extent of their authority within (a reworked) overarching framework. Matthias Åhrén's 'sliding scale' of self-determination' ${ }^{\text {'19 }}$ is helpful in elucidating how this might operate in practice. Acknowledging that delineating legal authority and political responsibility between Indigenous communities and the state is challenging, Åhrén proposes conceiving jurisdictional powers on a scale measuring 'the relative importance of the issue to the respective people'. ${ }^{120}$ As Åhrén explains:

It perhaps makes sense to posit that the more important the issue to the indigenous people's culture, society, and way of life, the greater influence the people should be allowed to exercise over the decision-making process. Conversely, if the matter is of little significance to the Indigenous people, but important to the welfare of society at large, Indigenous peoples' right to self-determination may only award the Indigenous people with limited influence over the decision-making process. Obviously, there are also matters in between. ${ }^{121}$

Åhrén's sliding scale is consistent with democratic values. As Robert Dahl has explained, democracy requires that those affected by a decision are entitled to have an equal say in the process used to reach that decision. ${ }^{22}$ Although democratic theorists have traditionally struggled to ascertain who is affected by some matter, or who is more relevantly affected, the principle remains clear: Indigenous polities should decide matters in cases where their resolution is considered to be more legitimately made by those polities. ${ }^{123}$

Some examples can be considered. For instance, the UNDRIP provides that Indigenous peoples have the right to autonomy or self-government 'in matters relating to their internal and local 
affairs' ${ }^{124}$ As the Declaration expands upon, this includes the ability to wield greater control over land and resources, as well as the authority to maintain, protect, and develop their religious, spiritual, and cultural traditions, and establish and control their own educational institutions. ${ }^{125}$ Among other things, in Australia this would empower Indigenous communities to choose whether formal educational teaching within their territory is conducted in traditional languages or English, or a combination of both. Although the state may be committed to ensuring a minimum standard of education, language instruction clearly affects Indigenous communities more than the state at large. Democratic theory suggests that agreements should be struck between relevant states and territories (who are constitutionally responsible for education) and Indigenous communities to embed this right.

Determining what constitutes 'internal and local affairs' or what otherwise should be the limits within which Indigenous self-rule is exercised may be difficult, but it does not negate the democratic right of Indigenous peoples to make decisions within that ambit. It also does not infringe the democratic rights of non-Indigenous peoples within the state. Rather, it recognises that over certain matters decisions should properly be made by Indigenous peoples themselves. It is this principle that properly precludes Australian citizens from voting on issues relating to New Zealand agricultural policy, or Victorians from matters 'internal and local' to Western Australia, and is driving the current push to ban political parties from accepting donations from foreign citizens. ${ }^{126}$ In these cases, the boundaries of the polity are clearly identified: New Zealand citizens are more relevantly affected by decisions relating to whether to import certain chemicals for agricultural use. Therefore, they are the polity who should be entitled to decide the resolution to that matter.

Globally, democratic states are recognising that democratic ideals mandate political or legal institutions to provide Indigenous peoples with the authority to exercise self-rule over certain matters. The Expert Mechanism on the Rights of Indigenous Peoples (EMRIP) has found that such mechanisms are not rare. ${ }^{127}$ For instance, Indigenous parliaments for the Sámi people exist in Norway, ${ }^{128}$ Sweden, ${ }^{129}$ and Finland. ${ }^{130}$ Each representative body differs in competencies, but broadly speaking, has administrative powers in certain areas and serves as a standing elected body that must be consulted with in all measures that may directly affect the Sámi people. Although originally designed as subordinate bodies whose power falls far from true autonomy or self-government, these parliaments may have gradually assumed a stronger role. Several scholars contend that the Norwegian Sámi Parliament, for example, no longer functions primarily as an advisory body but has been able to shift Sámi rights into 'political demands', ${ }^{131}$ transforming the Sámi people from 'an interest group' to 'a fully formal participant in public decision-making processes' ${ }^{132}$ Even if these comments are overstated, they suggest that institutional forms may evolve to more directly empower Indigenous political communities.

Reflecting the value of federalism as an institutional mechanism to provide for such authority, some states recognise autonomous regions whereby territorially concentrated Indigenous political communities are able to govern themselves. In Nicaragua for instance, the North Caribbean Coast Autonomous Region and the South Caribbean Coast Autonomous Region were established in 1987 and elected their first regional governments in 1990. Although the central government initially 'resisted granting any significant decision-making power or funds to the regional councils or governments', ${ }^{133}$ a successful challenge in the Inter-American Court of Human Rights by the Awas Tingni to expropriation of their traditional lands without consent, propelled action. ${ }^{134}$ A similar approach has been adopted in Canada and Denmark. In 1999, the territory of Nunavut was officially separated from the Northwest Territories, and in 2009 Greenland gained self-rule from Denmark. While both Nunavut and Greenland adopted a 
public (rather than ethnic) government, demographics mean that Inuit are a majority within the two polities. As such, within these territories, Inuit people exercise real autonomy in prescribed areas. In Nunavut, this encompasses, inter alia, legislative powers over the administration of justice, sale of land and property rights, education, marriage, and preservation of game, ${ }^{135}$ while in Greenland it extends to authority over judicial affairs, policing, and natural resources. ${ }^{136}$

In Australia, several mechanisms that recognise and provide for self-government by Indigenous polities exist or have existed previously. For example, on territory defined as Aboriginal Land under various statutory acts across Australia, Land Councils and Native Title Prescribed Body Corporates exercise a limited form of decision-making. Among other functions, Land Councils' must express and protect the interests of traditional owners, conciliate disputes between Indigenous people, and hold in trust and distribute payments from mining operations under negotiated agreements. ${ }^{137}$ These two statutory forms have created a 'carapace' for Indigenous decision-making, ${ }^{138}$ though one that remains severely limited. These bodies are not granted even limited self-governance powers, but rather powers more akin to self-management or self-administration. They are designed merely to protect and manage Aboriginal Land or native title and ensure certainty for governments and other parties interested in accessing land and waters. ${ }^{139}$ Additionally, they are limited to land defined under those Acts, and therefore offer little for Indigenous polities otherwise situated.

ATSIC was not so territorially delimited. As noted in Part II, the Commission had statutory authority to 'formulate and implement policy and programs for' Indigenous persons. ${ }^{140}$ As issues affecting Indigenous peoples are multifarious and cross-cutting, this permitted the Commission to develop policies on a wide breadth of matters. It was well-financed to satisfy these responsibilities: in 2002-2003, its final year of operation, ATSIC received around $\$ 1.3$ billion from the Commonwealth government. ${ }^{141}$ During its life, the Commission developed its independence from the state in various ways. ${ }^{142}$ In 1995, it obtained NGO status at the UN, providing it an ability to present interests distinct from the Australian government to international treaty bodies. ${ }^{143}$ Similarly, legislation passed in 1993, though deferred until 1 July 1996, enabled the Commission to elect its own Chair. ${ }^{144}$ However, while ATSIC was a positive step-forward in self-rule for Indigenous polities, it was never intended as an instrument of selfgovernment but rather 'a solid foundation' towards that goal. ${ }^{145}$ The priorities and policies identified by Indigenous representatives remained subject to review by the Minister and Parliament, and many scholars have therefore characterised ATSIC as an Indigenouscontrolled 'government department' ${ }^{146}$ rather than a true instantiation of democratic self-rule.

Modern treaties signed between the Canadian state and First Nations give clues as to the scope of democratic self-governance that could be recognised in Australia. Eight treaties have been negotiated under the British Columbia treaty process and although each is specific to the negotiating parties, as well as place, history and circumstance, they share several common elements, including governance rights. ${ }^{147}$ This typically encompasses the administration of justice, family and social services, healthcare, and language and cultural education, though federal and provincial law applies where an inconsistency or conflict arises. ${ }^{148}$ The Nisga'a Final Agreement was conducted outside the British Columbia process, but it too adopts a similar approach. Under the Treaty, the Nisga' a exercise their democratic right to self-rule via the Nisga'a Lisims government, 36-member Wilp Si'ayuukhl Nisga'a (legislature) and four village councils. Their authority extends over matters that directly affect the identity of the Nisga'a nation, including lands, language culture, education, health, child protection, traditional healing practice, fisheries, wildlife, forestry, environmental protection and 
policing. ${ }^{149}$ Once again, however, notwithstanding the broad ranging jurisdiction, its extent is limited in scope: federal and provincial laws apply where an inconsistency or conflict arises. ${ }^{150}$

That federal and provincial laws apply where an inconsistency or conflict arises can limit the democratic right of First Nations polities to determine internal and local matters for themselves, though it exists to ensure the central government retains authority to override decisions of its political subunits in the interests of the state as a whole. ${ }^{151}$ As a rule, decisions to override Indigenous lawmaking, or indeed lawmaking by any substate polity, should not be taken lightly. Rather, the central government should act with respect for the equal status of the Indigenous political community as a constituent normative order within the state. While this may not be able to be judicially enforceable, a political convention could arise to the effect that the government will not intervene or legislate with regard to matters under Indigenous authority without the consent of the Indigenous nation. ${ }^{152}$ In circumstances where the central government nonetheless wishes to legislate inconsistently with Indigenous decision-making, the government should genuinely consult with the relevant political community, seeking to accommodate their position as far as possible.

\section{Shared rule across multiple political communities}

So far, we have explored self-rule over certain matters for polities within the state as a condition of democratic governance. Of course, some other matters will properly be characterised as 'relevantly affecting' multiple polities within the state. Consistent with Åhrén's sliding scale and democratic theory more broadly, these decisions should not be decided solely by an Indigenous polity, but by the state at large. This points to the need for some structural interface between multiple peoples in which decisions on matters that relevantly affect all members of the state (including Indigenous peoples) can be negotiated, adjudicated and enforced. ${ }^{153}$

The state's constituent normative communities should be represented in relevant forums of decision-making, though the precise institutional arrangement can take multiple manifestations. Perhaps the most obvious is a system of reserved seats. More than thirty states reserve seats in their national parliaments for representatives of ethno-cultural minorities, ${ }^{154}$ while Indigenous peoples have guaranteed representation in New Zealand, Columbia and Venezuela. ${ }^{155}$ Reserved seats are also a condition of federal states, where representation of the constituent units of the state is expected, though this is often in upper houses where the government of the day is not formed. Dedicated seats can be particularly advantageous for numerically small political subunits, as they present the opportunity for members of such polities to have their voice heard in the state at large and 'set the agenda'. ${ }^{156}$ As Anne Phillips has explained, the real value of presence in representative institutions lies in the way it may 'transform the political agenda' by expanding the range of ideas and rendering visible what was invisible. ${ }^{157}$ Encouragingly, limited empirical evidence suggests reserved seats have a positive, though modest, effect in strengthening the voice of political minorities. ${ }^{158}$ Two challenges exist in Australia, however: first, affirming the fact that Australia's system of governance is predicated on a unitary demos, a system of reserved seats at the Commonwealth level would require constitutional amendment; second, accurately encompassing the scale and diversity of several hundred Aboriginal and Torres Strait Islander political communities in a state or federal Parliament would be difficult.

Alternative or additional extra-Parliamentary arrangements can also be devised. For example, Constitutional or Supreme Courts of many states operate under formal or conventional rules whereby seats are reserved for justices from different political subunits. ${ }^{159}$ In Canada, the 
Supreme Court Act 1985 guarantees at least three (of nine) positions on the Bench to individuals from Quebec. ${ }^{160}$ These seats are only eligible for current members of the Quebec bar or Quebec superior courts. ${ }^{161}$ By convention the other six positions are also divided, albeit less rigidly, amongst the provinces. ${ }^{162}$ In Belgium, the Constitutional Court is composed of twelve judges equally divided between two linguistic groups of 'six Dutch-speaking judges... and six French-speaking judges'. In addition, one of the 12 judges must have an adequate knowledge of German. ${ }^{163}$ Each linguistic group selects a President and 'the Presidency of the court as a whole alternates between these two each year'. ${ }^{164}$ Similarly, in the UK, by convention at least one judge from Scotland and one from Northern Ireland always sat on the House of Lords, the former ultimate appellate court. ${ }^{165}$ The Supreme Court of the United Kingdom, the successor to the House of Lords, appears to operate under a similar convention. The rationale for this convention is the same as that of reserved seats: members of the substate unit may be more likely to recognise decisions of the Court as legitimate if a member of their community is present in the forum of decision-making. Certainly, reserving a seat for an Indigenous justice may better incorporate Indigenous traditions into the Australian common law, leading to a more equitable overarching shared-rule framework and increasing the legitimacy of the law in the eyes of Indigenous peoples.

ATSIC was an innovative attempt at including Indigenous peoples within shared-rule institutions. Under s 7 of the ATSIC Act, the Commission was required to 'advise the Minister' on matters relating to Aboriginal and Torres Strait Islander affairs, as well as develop policy and implement programs for Aboriginal and Torres Strait Islanders. While the Minister was not 'restricted to, nor bound by the advice received', ${ }^{166}$ this statutory right provided 'significant advantages' to the Commission, relative to the multiplicity of Indigenous organisations across the country, ${ }^{167}$ as it guaranteed Aboriginal and Torres Strait Islander peoples' the capacity to have their interests heard in the processes of government via representatives of their choice. In fact, ATSIC not only had the authority to directly advise the Minister, but, when requested, could provide co-ordination comments on Cabinet submissions - a right no other group held. ${ }^{168}$

Nonetheless, in practice, the government often chose to ignore ATSIC's advice, and reports indicated 'a significant decline over time in ATSIC's input and access to the Cabinet policy development process' ${ }^{169}$ Concern that ATSIC's value and role as an institutional arrangement designed to empower Indigenous peoples in shared-decision-making was waning catalysed various proposals to expand the Commission's standing. These included proposals to make ATSIC's Chairperson 'a full member of the Ministerial Council on Aboriginal and Torres Strait Islander Affairs', ${ }^{170}$ or a member of the Council of Australian Governments. ${ }^{171}$ ATSIC itself recommended legislation providing the Chairperson with the right: to observer status in Parliament; to speak to either House on bills affecting Indigenous interests; and, to make an annual report to the nation on Indigenous affairs. ${ }^{172}$ ATSIC also considered that reserved seats at both the Commonwealth and state level, ward structures in local government areas with significant Aboriginal communities, and greater Indigenous representation on local councils would assist in this project. ${ }^{173}$ None of these proposals were adopted during ATSIC's existence.

Most recently, Aboriginal and Torres Strait Islander people have expressed support for a constitutionally entrenched representative body empowered to give First Nations a voice in laws that affect them. ${ }^{174}$ Although details have not been finalised, in most accounts, the body would be constitutionally enshrined, and empowered to advise Parliament on all matters affecting Aboriginal and Torres Strait Islander peoples. The advice would be tabled in Parliament and considered by both Houses when debating proposed laws. It would, however, be non-binding and non-justiciable. In the absence of any national Aboriginal and Torres Strait 
Islander institution, a First Nations Voice along these lines would be beneficial; enabling Indigenous Australians to have their voices heard over matters that affect them. And yet, in the absence of mechanisms of self-rule, the body would not be sufficient on this rehabilitated account of democratic theory; Indigenous Australians would remain unable to decide matters for themselves. That said, the First Nations Voice could complement institutional arrangements of self-rule at the local and community level.

Notwithstanding the multiplicity of shared-rule arrangements, some academics have questioned whether there is a tension between assertions of Indigenous sovereignty and participation in shared-rule institutions. For instance, Will Kymlicka has noted that the right to self-government is 'a right against the authority of the federal government, not a right to share in the exercise of that authority'. ${ }^{175}$ Similarly, Alexander Reilly has suggested that advocacy for specific Indigenous representation in Parliament is 'at odds' with calls for greater selfgovernment arrangements. ${ }^{176}$ Echoing this, Melissa Williams explains that enhanced representation in mainstream Canadian legislative institutions 'has not, by and large, been a goal of Aboriginal leaders or scholars in Canada, primarily because it appears to stand at odds with the more important goal of Aboriginal self-government'. ${ }^{177}$

If these views are premised on Indigenous peoples seeking secession, then they are correct. Only the most radical boundary theorists would suggest, for example, that Australians should have any direct influence on New Zealand agriculture law and policy. If Indigenous polities secede from the state, there is little accepted democratic justification for their presence on mechanisms of shared rule. As noted above, however, while some Aboriginal and Torres Strait Islander people may advocate secession, many have more moderate aims. As the Uluru Statement from the Heart indicates, Aboriginal and Torres Strait Islander peoples argue that their (spiritual) sovereignty 'co-exists with the [legal] sovereignty of the Crown', and as such, they seek structural reforms to 'empower our people and take a rightful place' within the state. ${ }^{178}$ These are not secessionist goals. Even Michael Mansell, former Secretary of the Aboriginal Provisional Government, accepts that Aboriginal people are 'not entitled to secession" ${ }^{179}$ under international law, nor in a position to demand 'full-blown selfdetermination'. 180

Participation in institutions of shared-rule is thus not at odds with Indigenous assertions of sovereignty but is reflective of a democratic theory receptive and sensitive to the fact of multiple peoples. As the New Zealand Royal Commission on Electoral Systems explained in 1986, representation of the rights and interests of a numerically smaller polity is 'essential' for two reasons. ${ }^{181}$ First, like a shield, their participation provides a measure of protection, ensuring that existing domains of self-rule are not threatened, or like ATSIC, abolished. Second, like a sword, participation is required because they are relevantly affected by economic and social policies enacted by the central government. Failure to have their interests heard will therefore affect the normative legitimacy of the decision. In this second dimension, participation in shared-rule institutions aims at ensuring 'a broader goal of self-government', ${ }^{182}$ and 'advancing Indigenous self-determination by targeting a variety of parallel and complementary access points to political power'. ${ }^{183}$ The presence of Indigenous representatives on shared rule institutions not only permits direct participation in decision-making processes, but offers meaningful opportunities to contest power otherwise wielded by non-Indigenous peoples. ${ }^{184}$ Of course, in multinational states, Indigenous peoples will not be successful in every issue but their voice must be heard. ${ }^{185}$ 
Hearing Indigenous peoples' voices requires genuine institutions of shared rule. As Dale Turner explains this does not mean simply incorporating Indigenous peoples into existing settler-state institutions, but restructuring those institutions so as they 'accommodate and respect Aboriginal voices on their own terms'. ${ }^{186}$ Morgan Brigg and Lyndon Murphy make a similar point, warning us not to "wrongly interpret the simple participation of Indigenous people [in settler-state institutions] as evidence of the expression of Indigenous ideas and values'. ${ }^{187}$ Although a bicultural interaction 'might occur', if it is premised on 'only one set of political values and ideas', ${ }^{188}$ it will likely fail to do justice to the rights and interests of Indigenous peoples. As these scholars identify, institutional procedures within the shared-rule framework are critical because those procedures shape how debate is conducted, and in so doing shape the terms of that debate.

These interventions caution against unreflective amendments to shared-rule institutions. For instance, reserving a number of seats in the Australian Parliament for Aboriginal and Torres Strait Islander peoples is justifiable on a democratic theory re-centred on the fact of multiple polities, but it would not be sufficient. While it would constitute a step forward, ensuring representatives accountable to Indigenous peoples are present in the shared law-making forum and providing greater opportunity for Indigenous interests to be heard on legislation that relevantly affects Indigenous peoples, their ability to disseminate Indigenous ideas and values would be limited. Absent additional changes to the structure or norms of the Australian Parliament, dedicated Indigenous Parliamentarians would merely 'constitute a minority in the institution of the majority'. ${ }^{189}$ Consistent with a robust and equitable democratic theory, changes to parliamentary procedures to ensure that the state listens would also be necessary.

\section{Conclusion}

Audra Simpson has argued that political science has not been able to 'harness[] the conceptual tools to engage the possibility of Indigenous nationhood; nor could [it] do it in ways that were consistent with the words and actions of the subjects'. ${ }^{190}$ Australia's democratic governance framework is similarly impoverished in this regard, unable to comprehend Indigenous assertions of sovereignty that challenge the presumed unitary demos. It is not unsalvageable, however. Recognition of plural wills within a postcolonial state; what Fiona MacDonald calls democratic multinationalism, ${ }^{191}$ and Duncan Ivison refers to as 'constellations of normative orders', ${ }^{192}$ is supportive of legal and political institutions and processes to provide Indigenous peoples' with the capacity to have their interests heard in the processes of government. Consistent with democratic theory, on - at the very least - matters 'internal and local', Indigenous peoples' interests should take precedence. Within this jurisdictional ambit they are, if they so choose, entitled to maintain analytically distinct legal and normative orders of selfrule. For other matters, Indigenous peoples' interests should be considered as part of a sharedrule framework where all polities within the state can be heard. Establishing institutions to embed this structural relationship for each First Nation across Australia may require some imaginative thinking, but this does not negate the moral force of their claims.

Part of the challenge is the absence of a foundational theory, practice, or act, that can facilitate this change in Australia. In Canada, Aotearoa/New Zealand, and the United States, historic treaties serve as an example of the institutional arrangements explored in this paper; a model based on the equal sharing of political power. Of course, those historic treaties were generally ignored by the state but their existence betrays an alternative path and scholarly and activist effort at recovering and implementing the procedural and substantive principles that were embedded in those treaties reveals their continuing force. ${ }^{193}$ Early efforts towards treaty- 
making in Western Australia, Victoria, and the Northern Territory, suggest displacing the unitary demos and re-centring Australia's democratic foundations may be possible. If substantive agreements are eventually reached, institutional arrangements that distribute political power across and within distinct normative communities may eventuate. ${ }^{194}$

Recognising the plurality of Australian society and establishing institutions to express those distinctions is important, but it should not come at the expense of a shared identity. While in the Uluru Statement, First Nations called on non-Indigenous Australians to "walk with us in a movement of the Australian people for a better future', future research should investigate how Australian citizenship may be reconceptualised in a manner that accepts Indigenous peoplehood. ${ }^{195}$ The goal is a society in which 'democratic self-government is distributed in such a way that citizens "participate concurrently in different collectivities", ${ }^{196}$ while also participating within the overarching state. Multinational federalism suggests one way that this can be realised. 


\section{End Notes}

1. Referendum Council (2017) p i.

2. Dodson and Cronin (2011) p 193.

3. Pearson (2007).

4. See for example: Dahl (1956) p 36; Ely (1980) p 73; Shapiro (2003) p 76.

5. Pitty (2009) p 29.

6. Nootens (2013) p 58.

7. Dodson (1997) p 59; Rowse (2000) p 86.

8. Keating (2001) p 39.

9. See e.g. Watson (2015).

10. Referendum Council (2017) p i.

11. Referendum Council (2017) p i.

12. Newman (2017) p 225.

13. Pettit (2012) p 22.

14. Pogge (1997) p 179.

15. Williams (2000) p 648.

16. Constitution of Australia (1901), ss. 25, 127.

17. Commonwealth Electoral Act 1962 (Cth) s. 2. See Goot (2006) pp 518-532 for complexities.

18. Hobbs (2018) p 176.

19. Davis and Lemezina (2010) p 241.

20. Davis (2016) p 86 (emphasis in original).

21. Laws (2000).

22. Robbins (2007) p 315.

23. Anderson (1983).

24. Simpson (2014) p 16.

25. Howard quoted in Behrendt (2003) p 3. See further Ivanitz (2002).

26. Referendum Council (2017) i; Anaya (2004) p 21; Schulte-Tenckhoff (2012) p 68.

27. Kymlicka (2011) p 188. See UNDRIP arts 6, 8(1)-(2), 9, 33, 36(1).

28. See for example Native Title Act 1993 (Cth).

29. See for example Aboriginal and Torres Strait Islander Heritage Protection Act 1984 (Cth).

30. Lino (2017) p 121. See further Rowse (1992).

31. Moore (1902) p 329.

32. Rowe v Electoral Commissioner (2010) 243 CLR 1 at 112 [344] (Crennan J).

33. McKinlay v Commonwealth (1975) 135 CLR 1, 24 (Barwick CJ).

34. Ludwick (2016) p 45.

35. Cronin (2017) p 235.

36. Māori Representation Act 1867 (NZ).

37. Electoral Act 1993 (NZ) s 45.

38. Commonwealth of Australia (2012) p 95. See further Reilly (2001) p 96.

39. Department of Prime Minister and Cabinet 2017.

40. UNGA, 61st sess, 107th plen mtg, UN Doc A/61/PV.107 (13 September 2007) p 11 (Hill, Australia).

41. UNGA, 61st sess, 107th plen mtg, UN Doc A/61/PV.107 (13 September 2007) p 13 (McNee, Canada).

42. UNGA, 61st sess, 107th plen mtg, UN Doc A/61/PV.107 (13 September 2007) p 14 (Banks, New Zealand).

43. United States Department of State (2007).

44. Gover (2015) p 345.

45. Aboriginal and Torres Strait Islander Commission Act 1989 (Cth) s 7.

46. Commonwealth, Parliamentary Debates, House of Representatives, 11 April 1989, p 1328 (John Howard).

47. Commonwealth, Parliamentary Debates, Senate, 18 August 1989, p 395 (Jim Short); Commonwealth, Parliamentary Debates, Senate, 30 August 1989, p 641 (Florence Bjelke-Petersen); 11 April 1989, p 1341 (Chris Miles) (a 'black power parliament').

48. Commonwealth, Parliamentary Debates, Senate, 17 October 1989, p 2014 (Jim Short) (discussing the Preamble to the Bill).

49. Aboriginal and Torres Strait Islander Commission Amendment Act 2005 (Cth).

50. ABC Radio National (2004).

51. Grattan (2004).

52. Vanstone (2004) p 4.

53. See Arcioni (2014a).

54. Referendum Council (2017) p i.

55. Tierney (2007) pp 230-231; Nootens (2009) p 281. 
56. Moreton-Robinson (2017). Even multiculturalism, which offers public and private space for minority groups to maintain and develop their culture, heritage and traditions, remains an integrative policy that ignores aspirations for autonomy: Kane (1997) p 541.

57. Tierney (2017) p 235. See also Requejo (2004) p 37.

58. On persistent electoral minorities and democratic design see Hobbs (2017) p 341.

59. Dahl (1970) p 49.

60. Nicholas (2014) p 111.

61. Temin (2016) p 96.

62. Nimni (2015) pp 61-62.

63. As Sákéj Youngblood Henderson explains, undifferentiated citizenship rights bestowed by the settler state, 'offer[]only the silence and anguish of minority interest group status': Henderson (2002) p 433.

64. Temin (2016) 121.

65. Australian Electoral Commission (2016) pp 18, 45.

66. Kauanui (2008) p 635. See further Bruyneel (2007) p 19.

67. Rawls (1999) p 327.

68. Taylor (2002) p 239.

69. Pildes (2004) p 2 (describing, not endorsing this account).

70. Tubman (1951) p 508.

71. Nootens (2008) p 277. An electoral loss may refer to a defeat on the floor of either House of Parliament, but it can also refer to a recurrent failure to have issues of considerable importance even debated in Parliament.

72. Human Rights Act 2004 (ACT); Charter of Human Rights and Responsibilities Act 2006 (Vic).

73. See for example Williams and Reynolds (2017).

74. The prohibition of racial discrimination was central to the decision in Mabo v Queensland (No 2) (1992) 175 CLR 1.

75. Kingsbury (2001) p 189.

76. Lino (2010) p 860.

77. Aroney, Prasser and Taylor (2012) pp 274-278.

78. Official Record of the Proceedings and Debates of the Australasian Federation Conference, Melbourne, 10 February 1890, 20.

79. Cole (1971) p 511.

80. Riker (1964).

81. Resnick (1994) p 71.

82. Mansell (2016).

83. Lino (2017) p 128.

84. Dicey (1959) p 141.

85. Newman (2017) p 217.

86. Tierney (2017) p 236; Mörkenstam (2015) p 641.

87. Arcioni (2014b) p 18; Lino (2018) pp 243-247; Nichols (2011) p 111.

88. Constitution of Australia, s. 128; Bistricic v Rokov (1976) 135 CLR 552, at 566 (Murphy J); Australian Capital Television Pty Ltd v Commonwealth (1992) 177 CLR 106, at 138 (Mason CJ); Theophanous v Herald \& Weekly Times Ltd (1994) 182 CLR 104, at 171 (Deane J); McGinty v Western Australia (1996) 186 CLR 140, at 230 (McHugh J).

89. Cabrera (2014) p 229.

90. Blokker (2011) p 406.

91. Greenfeld (1992) p 10.

92. Miller (1995) p 30.

93. de Tocqueville (1835) p 373.

94. Mill (1861) p 232.

95. Nootens (2013) p 58; Rosenfeld (1993) p 502.

96. Declaration of the Rights of Man and Citizen, 1789, art 6.

97. Keitner (2007) p 43.

98. Hont (1994) p 192.

99. Tully (1995) p 63.

100. Tully (1995) p 63. See also Parekh (2000) pp 181-183.

101. Chambers (2004) p 155.

102. Nootens (2009) p 279.

103. Dahl (1999) pp 119-131.

104. Shapiro and Hacker-Cordon (1999) p 1.

105. Dahl (1999) p 3; Carens (2005) p 1; Yack (2001) p 523.

106. Whelan (1983) p 16. See also Dworkin (2011) p 382. 
107. Espejo (2014) p 474.

108. Goodin (2007) p 43.

109. Young (2000) p 52.

110. Gover (2010) p 63; See also Gover (2014) p 201.

111. Though Cf. MacDonald (2014) p 608.

112. See for example Goodin (2007); Arrhenius (2005); Dahl (1970) p 64; Cohen (1971) p 8.

113. Held (2004) p 371.

114. Saunders (2000); Reilly (2006); McMillan (2016); Crowe (2016); Lino (2017).

115. Lino (2017) p 124.

116. Temin (2016) p 95.

117. Harty and Murphy (2005) p 80.

118. Monture-Angus (1999) p 12.

119. Åhrén (2016) p 138-143.

120. Åhrén (2016) p 139.

121. Åhrén (2016) p 139.

122. Dahl (1999) pp 97-105; Dahl (1998) pp 69-80.

123. Roughan (2013) p 213; Held (2004) p 371.

124. UNDRIP art 4.

125. UNDRIP arts 8, 10-15, 25-26. See further Kalkaringi (1998).

126. Joint Standing Committee on Electoral Matters (2017) p 39, Recommendation 3; Electoral Amendment (Banning Foreign Donations) Bill 2017.

127. Human Rights Council (2011).

128. Lov om Sametinget og andre samiske rettsforhold (1987)

129. Sametingslag (1992)

130. Act on the Sámi Parliament (1995).

131. Josefsen (2011) p 36. See also Robbins (2015) p 73.

132. Falch, Selle and Strømsnes (2016) p 135.

133. Larson and Lewis-Mendoza (2012) p 183.

134. The Case of the Mayagna (Sumo) Awas Tingni Community v Nicaragua, Inter-Am. Ct. H.R. (Ser. C) No. 79 (Judgment on merits and reparations of 31 August 2001).

135. Nunavut Act SC 1993, c. 28, s 23.

136. Act on Greenland Self-Government (Act No. 473, 2009) Ch 2, Schedule II.

137. Aboriginal Land Rights (Northern Territory) Act 1976 (Cth) s 23. Prescribed Bodies Corporate undertake similar tasks: Native Title Act 1993 (Cth) s 55.

138. Frith (2013).

139. Native Title (Prescribed Bodies Corporate) Regulations 1999 (Cth) reg 6.

140. Aboriginal and Torres Strait Islander Commission Act 1989 (Cth) s 7(1) (emphasis added).

141. Pratt and Bennett (2004) p 8.

142. Sanders (2002).

143. Sanders (2005) p 203.

144. Aboriginal and Torres Strait Islander Commission Act (No. 3) 1993 (Cth) Part 31 and Schedule 4.

145. Commonwealth, Parliamentary Debates, House of Representatives, 24 August 1988, p 252 (Gerry Hand); Tickner (2001) p 48; O’Donoghue (1994) p 12.

146. Chesterman and Galligan (1998) p 213; Robbins (2010) p 269.

147. Godlewska and Webber (2007) pp 17-18; Hobbs and Williams (2018) p 18.

148. See Maa-nulth First Nations Final Agreement (2008) art 1.8.1.

149. Nisga'a Final Agreement (1999), Chps 10-12.

150. Nisga'a Final Agreement (1999), art 11(13). See further Rynard (2000) pp 217, 230-235.

151. Though note that First Nations jurisdiction is more limited than provincial jurisdiction.

152. A similar convention exists in the UK with regard Scotland: Sewel Convention. See: United Kingdom, Parliamentary Debates, House of Lords, 21 July 1998, vol 592, col 791 (Lord Sewel).

153. Mörkenstam (2015) p 644.

154. Krook and O'Brien (2010) p 253.

155. New Zealand: Maori Representation Act 1867 (NZ); Colombia: Constitution of Colombia, 6 July 1991, Arts 171, 176; Venezuela: Bolivarian Constitution of Venezuela, 20 December 1999, Art 125.

156. Catt and Murphy (2002) p 49.

157. Phillips (1995) p 176.

158. Hodzic and Mraovic (2015) p 418.

159. Shetreet (2009) p 311.

160. Supreme Court Act (RSC, 1985, c S-26), s 6. 
161. Reference re Supreme Court Act, ss 5 and 6 [2014] SCC 21

162. Three are selected from Ontario, two from the Western Provinces, and one from the Atlantic Provinces.

163. Special Act of 6 January 1989 on the Constitutional Court, arts 31 and 34.4

164. Comella (2009) p 45.

165. Shetreet (2009) p 311.

166. Senate Select Committee on the Administration of Aboriginal Affairs (1989).

167. Dillon (1996) p 100.

168. Hannaford, Huggins and Collins (2003a) p 36. This is, of course, reflective of the fact that Indigenous peoples are distinguishable from other interest or lobby groups.

169. Hannaford, Huggins and Collins (2003a) p 36.

170. Council for Aboriginal Reconciliation (1996) Recommendation 18.

171. Council for Aboriginal Reconciliation (1996) p 45. The 2003 Hannaford Review recommended the ATSIC Chair have observer status at COAG meetings for all discussions on Aboriginal and Torres Strait Islander Affairs: Hannaford, Huggins and Collins (2003b) Recommendation 44.

172. Aboriginal and Torres Strait Islander Commission (1995) Recommendation 26.

173. Aboriginal and Torres Strait Islander Commission (1995) para [4.27].

174. Referendum Council (2017) Recommendation 1. Pearson (2014); Cape York Institute (2014). The body bears some similarities to an Indigenous Review Council proposed by John Chesterman: Chesterman (2008) p 421.

175. Kymlicka (1993) p 74; Kymlicka (1998) p 114.

176. Reilly (2001) pp 84 and 97.

177. Williams (2004) p 93.

178. Referendum Council (2017) p i (emphasis in original).

179. Mansell (2016) p 187.

180. Mansell (2016) p 195. See also Curry (2000) p 38.

181. New Zealand Royal Commission on Electoral Systems (1986) p 87.

182. Geddis (2006) p 348.

183. Murphy (2008) p 186.

184. MacDonald (2014) p 614. See also Phillips (1995) pp 126 and 136.

185. New Zealand, Royal Commission on Electoral Systems (1986) p 87.

186. Turner (2006) p 94. See also Tully (2005) pp 213-214.

187. Brigg and Murphy (2011) p 16.

188. Brigg and Murphy (2011) p 21.

189. Roughan (2005) p 298.

190. Simpson (2014) p 35

191. MacDonald (2014).

192. Ivison (2016) p 15.

193. Borrows and Coyle (2017).

194. Hobbs and Williams (2018) p 1.

195. For an approach premised on treaty federalism see Hobbs (2018) p 176.

196. Tully (2001) p 10 citing Reference re Secession of Quebec [1998] 2 SCR 217 at [66]. 


\section{Sources}

$\underline{\text { Cases }}$

- $\quad$ Australian Capital Television Pty Ltd v Commonwealth (1992) 177 CLR 106.

- $\quad$ Bistricic v Rokov (1976) 135 CLR 552.

- $\quad$ McGinty v Western Australia (1996) 186 CLR 140.

- McKinlay v Commonwealth (1975) 135 CLR 1.

- Mabo v Queensland (No 2) (1992) 175 CLR 1.

- $\quad$ Reference re Secession of Quebec [1998] 2 SCR 217.

- $\quad$ Reference re Supreme Court Act, ss 5 and 6 [2014] SCC 21.

- $\quad$ Rowe v Electoral Commissioner (2010) 243 CLR 1.

- $\quad$ Theophanous $v$ Herald \& Weekly Times Ltd (1994) 182 CLR 104.

- $\quad$ The Case of the Mayagna (Sumo) Awas Tingni Community v Nicaragua, Inter-Am. Ct. H.R. (Ser. C) No. 79 (Judgment on merits and reparations of 31 August 2001).

$\underline{\text { Legislation }}$

- Aboriginal and Torres Strait Islander Commission Act 1989 (Cth).

- Aboriginal and Torres Strait Islander Commission Act (No. 3) 1993 (Cth).

- Aboriginal and Torres Strait Islander Commission Amendment Act 2005 (Cth).

- $\quad$ Aboriginal and Torres Strait Islander Heritage Protection Act 1984 (Cth).

- $\quad$ Aboriginal Land Rights (Northern Territory) Act 1976 (Cth).

- Act on Greenland Self-Government (Act No. 473, 2009). (Denmark).

- Act on the Sámi Parliament 1995 (Finland).

- Bolivarian Constitution of Venezuela, 20 December 1999 (Venezuela).

- Charter of Human Rights and Responsibilities Act 2006 (Vic).

- Commonwealth Electoral Act 1962 (Cth).

- Constitution of Australia (1901).

- Constitution of Colombia (6 July 1991).

- Declaration of the Rights of Man and Citizen, 1789 (France).

- Electoral Act 1993 (NZ).

- Human Rights Act 2004 (ACT).

- $\quad$ Lov om Sametinget og andre samiske rettsforhold 1987 (Norwat).

- $\quad$ Māori Representation Act 1867 (NZ).

- Native Title Act 1993 (Cth).

- $\quad$ Native Title (Prescribed Bodies Corporate) Regulations 1999 (Cth).

- Nunavut Act SC 1993, c. 28. (Canada).

- Sametingslag 1992 (Sweden).

- $\quad$ Special Act of 6 January 1989 on the Constitutional Court (Belgium).

- $\quad$ Supreme Court Act (RSC, 1985, c S-26) (Canada).

$\underline{\text { Treaties and Declarations }}$

- $\quad$ Maa-nulth First Nations Final Agreement (2008).

- Nisga'a Final Agreement (1999).

- United Nations Declaration on the Rights of Indigenous Peoples, GA Res 61/295, UN GAOR, $61^{\text {st }}$ sess, 107th plen mtg, Supp No 49, UN Doc A/RES/61/295 (13 September 2007).

- United Nations General Assembly, 61st sess, 107th plen mtg, UN Doc A/61/PV.107 (13 September 2007).

- United States Department of State (2007) 'Explanation of Vote on the Declaration on the Rights of Indigenous Peoples’ http://www.ucs.louisiana.edu/ ras2777/indianlaw/usresponse.htm.

$\underline{\text { Reports }}$

- Aboriginal and Torres Strait Islander Commission (1995) Recognition, Rights and Reform: A Report to Government on Native Title Social Justice Measures.

- Commonwealth of Australia (2012) Recognising Aboriginal and Torres Strait Islander Peoples in the Constitution: Report of the Expert Panel.

- Council for Aboriginal Reconciliation (1996) Going Forward: Social Justice for the First Australians. 
- John Hannaford, Jackie Huggins and Bob Collins (2003a) Review of the Aboriginal and Torres Strait Islander Commission (Discussion Paper).

- John Hannaford, Jackie Huggins and Bob Collins (2003b) In the Hands of the Regions - A New ATSIC (Report of the Review of the Aboriginal and Torres Strait Islander Commission).

- Human Rights Council (2011) Final Report of the Study on Indigenous Peoples and the Right to Participate in Decision-Making: Report of the Expert Mechanism on the Rights of Indigenous Peoples, 18th sess, Agenda Item 5, UN Doc A/HRC/18/42.

- Joint Standing Committee on Electoral Matters (2017) Second Interim Report on the Inquiry into the Conduct of the 2016 Federal Election: Foreign Donations.

- Kalkaringi Constitutional Convention of the Combined Aboriginal Nations of Central Australia (1998).

- New Zealand Royal Commission on Electoral Systems (1986) Towards a Better Democracy.

- Referendum Council (2017) Final Report of the Referendum Council.

- Senate Select Committee on the Administration of Aboriginal Affairs (1989) Administration of Aboriginal Affairs.

\section{$\underline{\text { Submissions to Inquiries }}$}

- Australian Electoral Commission (2016) Submission No 66 to Joint Standing Committee on Electoral Matters, Inquiry into and Report on All Aspects of the Conduct of the 2016 Federal Election and Matters Related.

- Cape York Institute (2014) Submission No 38 to the Joint Select Committee on Constitutional Recognition of Aboriginal and Torres Strait Islander Peoples.

\section{Articles and Books Chapters}

- Mattias Åhrén (2016) Indigenous Peoples' Status in the International Legal System, Oxford University Press.

- James Anaya (2004) 'International Human Rights and Indigenous Peoples: The Move Towards the Multicultural State' 21 Arizona Journal of International and Comparative Law 13.

- Benedict Anderson (1983) Imagined Communities: Reflections on the Origin and Spread of Nationalism, Verso.

- Elisa Arcioni (2014a) 'Tracing the Ethno-Cultural or Racial Identity of the Australian Constitutional People' 15 Oxford University Commonwealth Law Journal 173.

- Elisa Arcioni (2014b) 'Excluding Indigenous Australians from "The People": A Reconsideration of s 25 and 127 of the Constitution' 40 Federal Law Review 1.

- Nicholas Aroney, Scott Prasser and Alison Taylor (2012) 'Federal Diversity in Australia: A CounterNarrative' in Gabrielle Appleby, Nicholas Aroney and Thomas John (eds), The Future of Australian Federalism, Cambridge University Press.

- Gustaf Arrhenius (2005) 'The Boundary Problem in Democratic Theory' in Folke Tersman (ed) Democracy Unbound: Basic Explorations I, Stockholm University Press.

- Larissa Behrendt (2003) Achieving Social Justice: Indigenous Rights and Australia's Future, Federation Press.

- Paul Blokker (2011), 'Modern Constitutionalism and the Challenges of Complex Pluralism' in Gerard Delanty and Stephen Turner (eds), Routledge International Handbook of Contemporary Social and Political Theory, Routledge.

- John Borrows and Michael Coyle (eds) (2017) The Right Relationship: Reimagining the Implementation of Historical Treaties, University of Toronto Press.

- Morgan Brigg and Lyndon Murphy (2011) 'Beyond Captives and Captors: Settler-Indigenous Governance for the 21st Century' in Sarah Maddison and Morgan Brigg (eds), Unsettling the Settler State: Creativity and Resistance in Indigenous Settler-State Governance, Federation Press.

- Kevin Bruyneel (2007) The Third Space of Sovereignty: The Postcolonial Politics of U.S.-Indigenous Relations, University of Minnesota Press.

- Luis Cabrera (2014) 'Individual Rights and the Democratic Boundary Problem' 6 International Theory 224.

- Joseph Carens (2005) 'Immigration, Democracy, and Citizenship' (Political Theory Workshop, University of Chicago).

- Helena Catt and Michael Murphy (2002) Sub-State Nationalism: A Comparative Analysis of Institutional Design, Routledge. 
- Simone Chambers (2004) 'Democracy, Popular Sovereignty, and Constitutional Legitimacy' 11 Constellations 153.

- John Chesterman and Brian Galligan (1998), Citizens Without Rights, Cambridge University Press.

- John Chesterman (2008) 'National Policy-Making in Indigenous Affairs: Blueprint for an Indigenous Review Council' 67 The Australian Journal of Public Administration 419.

- Carl Cohen (1971) Democracy, University of Georgia Press.

- Victor Comella (2009) Constitutional Courts and Democratic Values: A European Perspective, Yale University Press.

- Douglas Cole (1971) "'The Crimson Thread of Kinship": Ethnic Ideas in Australia, 1860-1914' 14 Historical Studies 511.

- $\quad$ Daryl Cronin (2017) 'Trapped by History: Democracy, Human Rights and Justice for Indigenous People in Australia' 23 Australian Journal of Human Rights 220.

- Jonathan Crowe (2016), 'The Race Power, Federalism and the Value of Subsidiarity for Indigenous Peoples' in Simon Young, Jennifer Nielsen and Jeremy Patrick (eds), Constitutional Recognition of First Peoples in Australia: Theories and Comparative Perspectives, Federation Press.

- $\quad$ Stephen Curry (2000) Indigenous Sovereignty and the Democratic Project, Ashgate.

- $\quad$ Robert Dahl (1956) A Preface to Democratic Theory, University of Chicago Press.

- $\quad$ Robert Dahl (1970) After the Revolution? Authority in a Good Society, Yale University Press.

- $\quad$ Robert Dahl (1998) On Democracy, Yale University Press.

- $\quad$ Robert Dahl (1999) Democracy and its Critics, Yale University Press.

- Megan Davis and Zrinka Lemezina (2010) 'Indigenous Australians and the Preamble: Towards a More Inclusive Constitution or Entrenching Marginalisation?' 33 UNSW Law Journal 239.

- Megan Davis (2016) 'Ships that Pass in the Night' in Megan Davis and Marcia Langton (eds), It's Our Country: Indigenous Arguments for Meaningful Constitutional Recognition and Reform, Melbourne University Press.

- Albert Venn Dicey (1959) Introduction to the Study of the Law of the Constitution (10th ed).

- Michael Dillon (1996) 'Institutional Structures in Indigenous Affairs: The Future of ATSIC' in Patrick Sullivan (ed), Shooting the Banker: Essays on ATSIC and Self-Determination, North Australian Research Unit.

- $\quad$ Mick Dodson (1997) 'Citizenship in Australia: An Indigenous Perspective' 22 Alternative Law Journal 57.

- $\quad$ Patrick Dodson and Daryl Cronin (2011), 'An Australian Dialogue: Decolonising the Country' in Sarah Maddison and Morgan Brigg (eds), Unsettling the Settler State: Creativity and Resistance in Indigenous Settler-State Governance, Federation Press.

- $\quad$ Ronald Dworkin (2011) Justice for Hedgehogs, Harvard University Press.

- Paulina Ochoa Espejo (2014) 'People, Territory, and Legitimacy in Democratic States' 58 American Journal of Political Science 466.

- John Hart Ely (1980) Democracy and Distrust: A Theory of Judicial Review, Harvard University Press.

- Torvald Falch, Per Selle and Kristin Strømsnes (2016) 'The Sami: 25 Years of Indigenous Authority in Norway' 15 Ethnopolitics 125.

- Angus Frith (2013) 'Native Title Corporations Achieving Capacity in Both Aboriginal and Australian Legal Systems' (Agreements, Treaties and Negotiated Settlements Symposium, Melbourne 25 June 2013).

- $\quad$ Andrew Geddis (2006) ‘A Dual Track Democracy?’ 5 Election Law Journal 347.

- $\quad$ Liah Greenfeld (1992) Nationalism. Five Roads to Modernity, Harvard University Press.

- Robert Goodin (2007) 'Enfranchising All Affected Interests, and its Alternatives' 35 Philosophy \& Public Affairs 43.

- Murray Goot (2006) 'The Aboriginal Franchise and its Consequences' 52 Australian Journal of Politics and History 517.

- Christina Godlewska and Jeremy Webber (2007) 'The Calder Decision, Aboriginal Title, and the Nisga'a' in Hamar Foster, Heather Raven and Jeremy Webber (eds), Let Right be Done: Aboriginal Title, the Calder Case, and the Future of Indigenous Rights, University of British Columbia Press.

- Kirsty Gover (2010), Tribal Constitutionalism: States. Tribes, and the Governance of Membership, Oxford University Press.

- Kirsty Gover (2014) 'Inter-Indigenous Recognition and the Cultural Production of Indigeneity in the Western Settler States' in Avigail Eisenberg et al (eds), Recognition versus Self-Determination: Dilemmas of Emancipatory Politics, University of British Columbia Press.

- Kirsty Gover (2015) 'Settler-State Political Theory, "CANZUS" and the UN Declaration on the Rights of Indigenous Peoples' 26 European Journal of International Law 345.

- $\quad$ Michelle Grattan (2004) 'PM jumps, ATSIC falls', The Sydney Morning Herald, 18 April 2004. 
- $\quad$ Siobhan Harty and Michael Murphy (2005) In Defence of Multinational Citizenship, University of British Columbia Press.

- David Held (2004) 'Democratic Accountability and Political Effectiveness from a Cosmopolitan Perspective' 39 Government and Opposition 364.

- Sákéj Youngblood Henderson (2002) 'Sui Generis and Treaty Citizenship’ 6 Citizenship Studies 415.

- Harry Hobbs (2017) 'Democratic Theory and Constitutional Design: Hearing Persistent Electoral Minorities' 24 International Journal on Minority and Group Rights 341.

- Harry Hobbs (2018) 'Constitutional Recognition and Reform: Developing an Inclusive Australian Citizenship through Treaty' 53 Australian Journal of Political Science 176.

- Harry Hobbs and George Williams (2018) 'The Noognar Settlement: Australia's First Treaty’ 40 Sydney Law Review 1.

- Edin Hodzic and Borisa Mraovic (2015) 'Political Representation of Minorities in Bosnia and Herzegovina: How Reserved Seats Affect Minority Representatives' Influence on Decision- Making and Perceived Substantive Representation' 15 Ethnopolitics 418.

- Istvan Hont (1994) 'The Permanent Crisis of a Divided Mankind: "Contemporary Crisis of the Nation State" in Historical Perspective' 42 Political Studies 166.

- Duncan Ivison (2016) 'Justification not Recognition' 8(24) Indigenous Law Bulletin 12.

- Michelle Ivanitz (2002) 'Democracy and Indigenous Self-Determination' in April Carter and Geoffrey Stokes (eds), Democratic Theory Today: Challenges for the 21st Century, Blackwell.

- Eva Josefsen (2011) 'The Norwegian Sami Parliament and Sami Political Empowerment' in Gunter Minnerup and Pia Solberg (eds), First World, First Nations: Internal Colonialism and Indigenous SelfDetermination in Northern Europe and Australia, Sussex Academic Press.

- John Kane (1997) 'From Ethnic Exclusion to Ethnic Diversity: The Australian Path to Multiculturalism' in Will Kymlicka and Ian Shapiro (eds), Ethnicity and Group Rights: Nomos XXXIX, New York University Press.

- J. Kehaulani Kauanui (2008) 'Colonialism in Equality: Hawaiian Sovereignty and the Question of U.S. Civil Rights' 107 South Atlantic Quarterly 635.

- $\quad$ Michael Keating (2001) 'So Many Nations, So Few States: Territory and Nationalism in the Global Era' in Alain-G. Gagnon and James Tully (eds), Multinational Democracies, Cambridge University Press.

- $\quad$ Chimene Keitner (2007), The Paradox of Nationalism, SUNY Press.

- Benedict Kingsbury (2001) 'Reconciling Five Competing Conceptual Structures of Indigenous Peoples' Claims in International and Comparative Law' 34 NYU Journal of International Law and Politics 189.

- Mona Krook and Diana O’Brien (2010) 'The Politics of Group Representation: Quotas for Women and Minorities Worldwide' 42 Comparative Politics 253.

- Will Kymlicka (1993) 'Group Representation in Canadian Politics' in F.L. Seidle (ed), Equity and Community: The Charter, Interest Advocacy and Representation, McGill-Queen's University Press.

- Will Kymlicka (1998) Finding Our Way, Oxford University Press.

- Will Kymlicka (2011) 'Beyond the Indigenous/Minority Dichotomy?' in Stephen Allen and Alexandra Xanthaki (ed), Reflections on the UN Declaration on the Rights of Indigenous Peoples, Hart.

- Anne Larson and Jadder Lewis-Mendoza (2012) 'Decentralisation and Devolution in Nicaragua's North Atlantic Autonomous Region: Natural Resources and Indigenous Peoples' Rights' 6 International Journal of the Commons 179.

- John Laws (2000) Interview with John Howard, Prime Minister of Australia (Sydney, 29 May 2000).

- Dylan Lino (2010) 'The Politics of Inclusion: The Right of Self-Determination, Statutory Bills of Rights and Indigenous Peoples' 29 Melbourne University Law Review 839.

- Dylan Lino (2017) 'Towards Indigenous-Settler Federalism' 28 Public Law Review 118.

- Dylan Lino (2018) 'Indigenous Recognition' in Rosalind Dixon (ed), Australian Constitutional Values, Hart.

- Harold Ludwick (2016) 'Through Black Eyes' in Megan Davis and Marcia Langton (eds), It's Our Country: Indigenous Arguments for Meaningful Constitutional Recognition and Reform, Melbourne University Press.

- Fiona MacDonald (2014) 'Democratic Multinationalism: A Political Approach to Indigenous-State Relations' 21 Constellations 608.

- Mark McMillan (2016) 'Is Federalism Being Undermined in the Current Surge to 'Recognise' Indigenous Australians in (and into) the Commonwealth Constitution?' 8(25) Indigenous Law Bulletin 15.

- $\quad$ Michael Mansell (2016) Treaty and Statehood: Aboriginal Self-Determination, Federation Press.

- John Stuart Mill (1861) Considerations on Representative Government, The Floating Press, 2009 (first published 1861).

- $\quad$ David Miller (1995) On Nationality, Oxford University Press. 
- Patricia Monture-Angus (1999) Journeying Forward: Dreaming First Nations' Independence, Fernwood.

- Aileen Moreton-Robinson (2017) 'Senses of Belonging: How Indigenous Sovereignty Unsettles White Australia’ http://www.abc.net.au/religion/articles/2017/02/21/4623659.htm.

- Ulf Mörkenstam (2015) 'Recognition as if Sovereigns? A Procedural Understanding of Indigenous SelfDetermination’ 19 Citizenship Studies 634.

- Harrison Moore (1902) The Constitution of the Commonwealth of Australia, John Murray.

- Michael Murphy (2008) 'Representing Indigenous Self-Determination' 58 University of Toronto Law Journal 185.

- Dwight Newman, 'Federalism and Democracy' in Amnon Lev (ed), The Federal Idea: Public Law Between Governance and Political Life, Hart.

- $\quad$ Robert Nichols (2011) 'Contract and Usurpation' in Andrea Smith and Audra Simpson (eds), Theorizing Native Studies, Duke University Press.

- Ephraim Nimni (2015) 'Minorities and the Limits of Liberal Democracy: Demoicracy and NonTerritorial Autonomy' in Tove Malloy and Francesco Palermo (eds), Minority Accommodation through Territorial and Non-Territorial Autonomy, Oxford University Press.

- Geneviève Nootens (2009) 'Democracy and Legitimacy in Plurinational Societies' 8 Contemporary Political Theory 276.

- Geneviève Nootens (2013) Popular Sovereignty in the West: Polities, Contention, and Ideas, Routledge.

- Lois O'Donoghue (1994) 'Keynote Address: Australian Government and Self-Determination' in Christine Fletcher, (ed), Aboriginal Self-Determination in Australia, Aboriginal Studies Press.

- Bhikhu Parekh (2000) Rethinking Multiculturalism: Cultural Diversity and Political Theory, Macmillan.

- $\quad$ Noel Pearson (2007) 'A Structure for Empowerment', The Weekend Australian, 16-17 June 2007.

- $\quad$ Noel Pearson (2014) 'A Rightful Place: Race, Recognition and a More Complete Commonwealth' 55 Quarterly Essay 1.

- Philip Pettit (2012) On the People's Terms: A Republican Theory and Model of Democracy, Cambridge University Press.

- $\quad$ Anne Phillips (1995) The Politics of Presence, Oxford University Press.

- Richard Pildes (2004) 'Democracy and the Representation of Minority Interests' in F. Bastida (ed), Fundamentos: La Representación Política, Asturias.

- Roderic Pitty (2009) 'The Unfinished Business of Indigenous Citizenship in Australia and New Zealand' in Klaus Neumann and Gwedna Tavan (eds), Does History Matter? Making and Debating Citizenship, Immigration and Refugee Policy in Australia and New Zealand, ANU Press.

- Thomas Pogge (1997) 'Creating Supra-National Institutions Democratically: Reflections on the European Union's “Democratic Deficit”' 5 The Journal of Political Philosophy 163.

- Angela Pratt and Scott Bennett (2004) 'The End of ATSIC and The Future Administration of Indigenous Affairs' (Parliamentary Library, 9 August 2004).

- Department of Prime Minister and Cabinet (2017) 'Response to Referendum Council's Report on Constitutional Recognition' https://ministers.pmc.gov.au/scullion/2017/responsereferendumcouncilsreport-constitutional-recognition.

- John Rawls (1999), 'Kantian Constructivism in Moral Theory' in Samuel Freeman (ed), John Rawls: Collected Papers, Harvard University Press.

- Alexander Reilly (2001) 'Dedicated Seats in the Federal Parliament for Indigenous Australians: The Theoretical Case and its Practical Possibility' 2 Balayi: Culture, Law and Colonialism 85.

- Alexander Reilly (2006) 'A Constitutional Framework for Indigenous Governance' 28 Sydney Law Review 403.

- $\quad$ Ferran Requejo (2004) 'Value Pluralism and Multinational Federalism' 50 Australian Journal of Politics and History 23.

- $\quad$ Philip Resnick (1994) 'Toward a Multination Federalism' in Leslie Seidle (ed), Seeking a New Canadian Partnership: Asymmetrical and Confederal Options, Institute for Research on Public Policy.

- William Riker (1964) Federalism: Origin, Operation, Significance, Little, Brown.

- Jane Robbins (2007) 'The Howard Government and Indigenous Rights: An Imposed National Unity?' 42 Australian Journal of Political Science 315.

Jane Robbins (2010) ‘A Nation Within?' 10 Ethnicities 257, 269.

Jane Robbins (2015) 'Indigenous Political Representation in Liberal-Democratic Countries: A Comparative Analysis' in Mikkel Berg-Nordlie, Jo Saglie and Ann Sullivan (eds), Indigenous Politics: Institutions, Representation, Mobilisation, ECPR Press.

Michael Rosenfeld (1993) 'Modern Constitutionalism as Interplay between Identity and Diversity: An Introduction’ 14 Cardozo Law Review 497. 
Nicole Roughan (2005) 'Te Tiriti and the Constitution: Rethinking Citizenship, Justice, Equality and Democracy' 3 New Zealand Journal of Public and International Law 285.

Nicole Roughan (2013) Authorities, Oxford University Press.

Tim Rowse (1992) Remote Possibilities: The Aboriginal Domain and the Administrative Imagination, North Australian Research Unit.

Tim Rowse (2000) 'Indigenous Citizenship' in Wayne Hudson and John Kane (eds), Rethinking Australian Citizenship, Cambridge University Press.

Paul Rynard (2000) “"Welcome In, But Check Your Rights at the Door”, The James Bay and Nisga'a Agreements in Canada' 33 Canadian Journal of Political Science 211.

Will Sanders (2002) 'Towards an Indigenous order of Australian government: Rethinking selfdetermination as Indigenous affairs policy' (CAEPR Discussion Paper No 230/2002).

Will Sanders (2005) 'CDEP and ATSIC as Bold Experiments in Governing Differently - But Where To Now?' in Diane Austin-Broos and Gaynor Macdonald (eds), Culture, Economy and Governance in Aboriginal Australia: Proceedings of a Workshop of the Academy of Social Sciences in Australia, University of Sydney, 30 November - 1 December 2004, Sydney University Press.

Cheryl Saunders (2000) 'The Implications of Federalism for Indigenous Australians' in Yash Ghai (ed), Ethnicity and Autonomy: Negotiating Competing Claims in Multi-Ethnic States, Cambridge University Press.

Isabelle Schulte-Tenckhoff (2012) 'Treaties, Peoplehood, and Self-Determination: Understanding the Language of Indigenous Rights' in Elvira Pulitano (ed), Indigenous Rights in the Age of the UN Declaration, Cambridge University Press.

Ian Shapiro and Casiano Hacker-Cordon (1999) 'Outer Edges and Inner Edges' in Ian Shapiro (ed), Democracy's Edges, Cambridge University Press.

Ian Shapiro (2003) The State of Democratic Theory, Princeton University Press.

Shimon Shetreet (2009) 'The Normative Cycle of Shaping Judicial Independence in Domestic and International Law' 10 Chicago Journal of International Law 275.

Audra Simpson (2014) Mohawk Interruptus: Political Life Across the Borders of Settler States, Duke University Press.

Peter Taylor (2002) 'Relocating the Demos?' in James Anderson (ed), Transnational Democracy: Political Spaces And Border Crossings, Routledge.

David Temin (2016) Remapping the World: Vine Deloria, Jr. and the Ends of Settler Sovereignty (PhD Thesis, University of Minnesota, October 2016).

Robert Tickner (2001) Taking a Stand: Land Rights to Reconciliation, Allen \& Unwin.

Stephen Tierney (2007) “We the Peoples": Constituent Power and Constitutionalism in Plurinational States' in Martin Loughlin and Neil Walker (eds) The Paradox of

Constitutionalism, Oxford University Press.

Stephen Tierney (2017) 'Federalism and the Plurinational Challenge' in Amnon Lev (ed), The Federal Idea: Public Law Between Governance and Political Life, Hart.

Alexander de Tocqueville (1835) Democracy in America (1835) (Henry Reeve trans, Oxford University Press 1961).

David Tubman (1951) The Governmental Process: Political Interests and Public Opinion, Alfred A. Knopf.

James Tully (1995) Strange Multiplicity: Constitutionalism in an Age of Diversity, Cambridge University Press.

James Tully (2001), 'Introduction' in Alain-G. Gagnon and James Tully (eds), Multinational Democracies, Cambridge University Press.

James Tully (2005) 'Exclusion and Assimilation: Two Forms of Domination in Relation to Freedom' in Melissa Williams and Stephan Macado (eds), NOMOS 46: Political Exclusion and Domination, New York University Press.

Dale Turner (2006), This is Not a Peace Pipe: Towards a Critical Indigenous Philosophy, University of Toronto Press.

Amanda Vanstone (2004) 'Opening Address', Bennelong Society (Sydney, 4 September 2004).

Irene Watson (2015) Aboriginal Peoples, Colonialism and International Law: Raw Law, Routledge.

Frederick Whelan (1983) 'Democratic Theory and the Boundary Problem' in J. Roland Pennock and John W. Chapman (eds), Liberal Democracy: Nomos XXV, New York University Press.

George Williams (2000) 'Race and the Australian Constitution: From Federation to Reconciliation' 38 Osgoode Hall Law Journal 643.

George Williams and Daniel Reynolds (2017) A Charter of Rights for Australia, NewSouth, 4th ed. 
Melissa Williams (2004) 'Sharing the River: Aboriginal Representation in Canadian Political Institutions' in David Laycock (ed), Representation and Democratic Theory, University of British Columbia Press.

- $\quad$ Bernard Yack (2001) 'Popular Sovereignty and Nationalism' 29 Political Theory 517.

- $\quad$ Iris Marion Young (2000) Inclusion and Democracy, Oxford University Press. 